\title{
Sarah Brouillette, UNESCO and the Fate of the Literary
}

\section{Kathie Birat}

\section{OpenEdition}

\section{Journals}

Electronic version

URL: http://journals.openedition.org/ces/4357

DOI: $10.4000 /$ ces.4357

ISSN: 2534-6695

\section{Publisher}

SEPC (Société d'études des pays du Commonwealth)

\section{Electronic reference}

Kathie Birat, "Sarah Brouillette, UNESCO and the Fate of the Literary », Commonwealth Essays and Studies [Online], 43.1 | 2020, Online since 30 October 2020, connection on 09 November 2020. URL http://journals.openedition.org/ces/4357 ; DOI : https://doi.org/10.4000/ces.4357

This text was automatically generated on 9 November 2020

\section{(c) (i) (9)}

Commonwealth Essays and Studies is licensed under a Licence Creative Commons Attribution - Pas d'Utilisation Commerciale - Pas de Modification 4.0 International. 


\title{
Sarah Brouillette, UNESCO and the Fate of the Literary
}

\author{
Kathie Birat
}

\section{REFERENCES}

Sarah Brouillette. UNESCO and the Fate of the Literary. Stanford: Stanford University

Press, 2019. 175 p. ISBN: 9781503610316 (pb). €21,50

1 At a time when the notions of world literature and the globalization of culture are being evoked with greater frequency, Sarah Brouillette's UNESCO and the Fate of the Literary serves as a timely reminder of the economic and political forces that affect the production and reception of literature. Brouillette's examination of the role of UNESCO since its creation makes it possible to understand what she calls "the realities of production" (4) in their relation to UNESCO's ideals and discredits any conception of literature as a level playing field. By giving an in-depth analysis of UNESCO's role, the author allows the reader to observe the ways in which an organization more often associated in people's minds with its support of World Heritage Sites was unable to achieve its initial goals with regard to literature. Beyond its value as a clear and welldocumented study of a complex organization, Brouillette's study serves as a reminder that creativity, writing, and publishing are governed by market forces.

Brouillette clearly states in her introduction that her work is motivated and informed by the cultural sociology of thinkers like Raymond Williams and Stuart Hall, whose approach to the cultural sphere was supported by UNESCO in the 1960s. It is on this basis that the author examines the "entanglements of power, culture and capitalism" (8) that can be observed in UNESCO's changing role with regard to books. She designates three phases in the history of the organization, each of which she identifies with a representative program, illustrated through the discussion of a work that encapsulates the issues at stake in each period. This approach contributes to the clarity 
of the discussion, allowing one to grasp the concrete consequences of policies expressed in official statements, which form the basis of Brouillette's documentation.

The first two chapters discuss the organization's "first major literary program" (21) which involved the establishing of a list of classics, chosen for their importance as landmarks of culture but also for their accessibility, some of which were translated into two or three major languages. Brouillette shows how, by linking the ideas of economic and cultural development, the program unwittingly reinforced the role of former colonial powers through an emphasis on modernization and progress. Chapter 2 uses the inclusion of Yasunari Kawabata's novel Snow Country in the list of Representative Works as an example of the problems underlying the choice of works meant to encourage cross-cultural understanding through the values of "liberal humanist internationalism" (42). The author argues that the aestheticization involved in Kawabata's narrative strategy makes the work compatible with the American desire to promote works expressing an "apolitical lyricism" (40).

In Chapters 3 and 4, Brouillette explains the source and development of the idea of "cultural policy," discussions of which made possible the expression of people's concern with the ways in which capitalism might threaten rather than preserve and encourage culture. It was during this period that UNESCO entered into what she calls "its most radical phase" (59), under the direction of Amadou-Mahtar M'Bow (19741987) and that the preservation of "unique cultural identities" (60) through direct state intervention became a priority. Western opposition to any type of reform aimed at correcting "the inequalities in the flow of information to and from developing countries" (93) led to the withdrawal of the United States and Great Britain from UNESCO in the 1980s. Brouillette suggests that the financial power wielded by the United States, which returned to UNESCO in 2003, only to exit definitively in response to UNESCO's acceptance of Palestinian membership, weighed heavily on the organization's capacity to defend the interests of developing nations, which were threatened with being reduced to the status of "net consumers of culture" (97).

These chapters provide a clear perception of the difficulties faced by an organization dependent on the financing provided by Western nations, although it might be remarked that the media and particularly the publishing industries within the Western nations themselves were undergoing pressures of concentration and merger that made it increasingly difficult for independent publishers and booksellers to survive. Brouillette's major contribution in these chapters is to an understanding of the hidden consequences of policies like book donation that hindered the development of local publishing in developing countries and perpetuated forms of "literary colonialism" (89).

6 Chapters 5 and 6 discuss the third period, in which culture has become a "resource" and in which UNESCO's support is essentially given to private-sector activities. The City of Literature program as a mark of cultural success rather than as a tool for correcting imbalances and the 2005 Convention on the Protection and Promotion of the Diversity of Cultural Expressions are given as examples of UNESCO's role as an "indirect support network" (109) in a cultural sector increasingly dominated by the logic of the marketplace. Chapter 6 looks at the crucial and controversial question of copyright through a discussion of the non-profit organization ZIMCOPY, which received a grant from UNESCO in 2013 in order to combat piracy and promote respect for copyright. Brouillette examines the failure of the project to encourage local creativity, using as an 
example NoViolet Bulawayo's popular novel We Need New Names, in which Bulawayo reveals the dark side of humanitarian aid and suggests that piracy can be a form of cultural resistance. She concludes her book with an evocation of the increasing role of China within the structure of UNESCO.

7 Although Brouillette is frank about the ideological underpinnings of her study, the reader may find her approach heavy-handed. Her bias is particularly obvious in her analysis of specific works, such as Zake Mda's The Heart of Redness, criticized for its failure to question "the value of integration into market-based commercial culture" (142). Sarah Brouillette's study of UNESCO offers useful insight into the impact of cultural policy, communications, and the culture industry on literary production. Yet, the reader is also apt to remain wary of overly deterministic interpretations of literature, which end up setting aside the transgressive, transformative, discrepant nature of the literary.

\section{AUTHORS}

\section{KATHIE BIRAT}

Université de Lorraine

Kathie Birat is Emeritus Professor of American, African American and Caribbean literature at the University of Lorraine. She has published numerous articles on writers from the Englishspeaking Caribbean, with particular emphasis on the work of Caryl Phillips. She edited a special issue of Commonwealth Essays and Studies devoted to Phillips (40.1, Autumn 2017). Among her recent publications are "Making Sense of Memory in the Writings of the Caribbean Diaspora: Sam Selvon's London Calypso," Journal of Postcolonial Writing 55.6 (2019) and “"Taak prappa': Voice, Orality and Absence in David Dabydeen's Slave Song," Sillages critiques 25 (2018). 